\title{
Conversation in Place and About Place: Response to Chimakonam, "Conversational Philosophy as a New School of Thought in African Philosophy: A Conversation with Bruce Janz on the Concept of "Philosophical Space"
}

BRUCE B. JANZ

University of Central Florida, Orlando, USA (Bruce.Janz@ucf.edu)

I respond to Jonathan Chimakonam's paper in which he presents an approach to dialogue in philosophical space, and raises questions about my own approach. I raise four questions to his understanding of conversation. First, I ask bim for more details on his conception of conversation. Second, what happens if not everyone cares to enter into conversation? Third, is conversation a prevequisite to philosophy, or a part of philosophy? And fourth, how does wonder fit into conversation in and about place?

Keywords: Chimakonam, dialogue, conversation, place, African philosophy, wonder

I would like to thank Journal of World Philosopbies and Dr. Jonathan Chimakonam for the opportunity to join this conversation about the nature of philosophical space in Africa, in response to his "Conversational Philosophy as a New School of Thought in African Philosophy" paper in an earlier issue. ${ }^{1}$ The major thrust of Chimakonam's paper is to establish and describe what he calls the "conversational" school of African philosophy. My comments will be directed at analyzing this project, including looking at the parallel projects that Chimakonam draws on, including my own philosophy-in-place. This new project of Conversational Philosophy has interesting potential, and certainly picks up on some significant currents in African philosophy. There are questions that are worth raising that I think can help with clarification of this project and of African philosophy in general.

\section{$1 \quad$ Dialogue and its Limits}

The first question comes out of a recent paper I did on the nature and limits of dialogue. In "Philosophyin-Place and the Provenance of Dialogue" in the South African Journal of Philosophy, I tried to tease apart some of the uses and misuses of the concept of dialogue, and suggest ways in which it obscured or sidetracked real creativity of concepts (Janz 2015). ${ }^{2}$ My starting point was two provocations from Deleuze and Guattari:

We can at least see what philosophy is not: it is not contemplation, reflection, or communication $[\ldots .].[C]$ ommunication [...] only works under the sway of opinions in order to create 'consensus' and not concepts. The idea of a Western democratic conversation between friends has never produced a single concept (Deleuze, and Guattari 1994: 6).

Journal of World Philosophies 1 (Winter 2016): 41-50 
[...] philosophers have very little time for discussion. Every philosopher runs away when he or she hears someone say, 'Let's discuss this.' [...] Communication always comes too early or too late, and when it comes to creating, conversation is always superfluous [...] (ibid.: 28). ${ }^{3}$

The argument I made in that paper was that dialogue, or conversation if we are using these as equivalent (and I recognize that Chimakonam uses these terms differently; Chimakonam 2015a: 20), but Deleuze and Guattari's use, as well as my own, seems closer to his sense of conversation than his sense of dialogue in that it is directed towards the development of concepts and not simply towards the exchange of ideas), has been used for a host of things that have not led to new concepts, and in that Deleuze and Guattari are correct. To the extent that dialogue continues to have the provenance of Plato's transcendentalism, it probably will not get too far at this point. Despite that, though, it need not have that as its goal (and this is something that Chimakonam would, I think, agree with). My aphorism for this was "Dialogue is dialect, but it is not dialectic." In this I attempted to build back in philosophy-in-place and avoid the pitfalls which have often come along with pieties about the virtues of dialogue. I wanted to emphasize difference rather than a teleology of unity or even understanding. And, I wanted to highlight some places within African philosophy in which dialogue has potential to give us a new problematic, that is, a new ecological space for asking questions that could not be asked previously. African philosophy has, in fact, had dialogue at its core in a more literal manner than other traditions, given that at least some conceptual development has happened through various oral traditions, and it is constantly navigating differences of language and culture in ways that most Western philosophy has not had to face, and even in the fact that traditions such as sage philosophy have actual dialogue with sages built into its method.

And so, in other words, dialogue has not been absent from African philosophy, but it has taken on a different valence, a mode of operation that has not necessarily depended on a teleology of transcendence. What arises from this, but I did not develop in that essay in any extensive manner, are several opportunities for dialogue which, while certainly not unknown elsewhere, might be fertile space for the development of concepts. Translation, for instance, is one of those-what are the possibilities for the creation of concepts when we attend to the polyglot nature of many African places, and do not think about philosophy as requiring a prerequisite of a single lingua franca such as English, German, or Latin? In connection with the tradition of orality, thinking about what listening means might be another. Thinking about dialogue in ways that do not privilege the exchange of propositions would be another-what would dialogue look like when it is the exchange of proverbs or stories or, for that matter, dances?

The relevance to Chimakonam's paper is this: I would like to ask in more specific terms what his concept of conversation looks like. He has given an extensive discussion of it in this essay, and also elsewhere, but it seems to me that there are still some unanswered questions. Dialogue, as I have argued, stands as both an object of investigation in philosophy and also as a prerequisite to philosophy. Does conversation also occupy the same conflicted position? Are we assuming a ground that itself needs analyzing, but in order to analyze it we have to assume that it exists and functions? Are there specific forms in which dialogue happens, or is this just a general category of conceptual engagement? Does it matter that dialogue has been worked out in mostly textual forms in the West? Does literal conversation count as philosophical labor, or does it need to be textualized to count? And what about the other side of conversation, listening? When we usually think of conversation, we think of speaking, that is, putting forward positions and opinions. Do we have a phenomenology of listening to go along with this? In what sense can silence also be philosophical labor, or is it? And, can we avoid the trap of "comparative philosophy," which is that we end up simply listing similarities and differences between positions and do not actually work towards any new concepts (this, I take it, is Deleuze and Guattari's concern, at least in part). 


\section{The Reasons for Conversation as a Philosophical Method}

The second major question: Why conversation and why conversation in place? It is not because of a dialectical move towards truth (here I agree with Chimakonam). It is not because we are coming to some agreement. It's because there is a world constructed within a conversation in place that could not have happened elsewhere, but which allows the creation of concepts. So, on the broad reason for conversation, I would agree with Chimakonam. But I think there's more to be done here, although it will take a small detour to sketch out what that is.

I had a student say to me once that he thought that Augustine's Confessions were "undoubtedly thought-provoking," but that he couldn't identify with them because he wasn't attached to religion. Now, it may well be that he wasn't attached to religion, but should that be the determining factor as to whether there something of philosophical value or interest in Augustine? Consider that example for a moment. Augustine works through a set of issues that come out of his search for a Christian God. "What do I love, when I love my God?" he asks. His orientation is within a North African Christian context, one in which neo-Platonism is well known, one in which there is a flow back and forth between early Christian theology, Jewish theology, mystery religions, Greek philosophy, and Roman thought, among other things. It was, in other words, thought that happened in a place, and part of that place was Augustine's own commitment to a central and guiding question.

Out of this search, we have a kind of proto-psychological treatise, in which he takes us through a kind of ascent through the various senses, through human faculties, in search of God. He finds God, and he has done it in a manner reminiscent of a Plotinian return to the source, but of course being Christian, it is not a flight from the alone to the Alone. It has a stopping point, because there is a fundamental gulf between Creator and created. And so, what he finds is not God but the image of God in humans, the Imago $D e i$, which has a Trinitarian form of memory, understanding, and will. This is worked out more fully in other writings, but along the way in the Confessions we get some seminal discussions on memory and time.

So, does one need to share Augustine's search to benefit from his discussion of memory or time? No. Does one need to agree with his conclusions on memory or time to understand their importance as concepts formed in a place, in response to a specific question that had its existential and geographical conditions? Again, no. What we need to be able to do is enter the conversation. It is, for him, a literal conversation at times-some of his writings are epistolary, some are imagined conversations with God. And, in entering the conversation and understanding the specificity of its conditions, we understand the potential and the limits of the concepts that are created in that place.

We even see Augustine creating concepts which, for others in other places at the same time would have been seen as strange or even outrageous. What do we make of this idea of the Trinity? Plotinus, Arius, and a host of others took a subordinationist path-if there is a Trinity, there is still one element that is predominant and others are secondary. Augustine does not take that route, and in De Trinitate he draws on a concept from Greek theatre, that of the "persona," to virtualize the Trinity as sets of relations. The ousia or substance remains one, while the bypostases or persons are three. They exist as coequal, and depend on relation for their existence. This concept of the person changes later with John Locke and others such that persons have a set of properties, and with René Descartes such that persons are more closely related to mind than body and therefore are known first and best, and later still with the Romantics to be an ocean of mystery and conflicting subconscious forces that we struggle to harness and rationalize. Augustine starts us on a path, and that path is the result of a conversation over something that non-religious people today may regard as quaint or strange - the question of the nature of the Trinity. Concepts, in other words, are vectors or virtualities which arise from the encounter of intellectual (among other) forces, and the fact that one may or may not agree with or understand the initial conditions of that encounter does not mean that

Journal of World Philosophies 1 (Winter 2016): 41-50

Copyright (C) 2016 Bruce B. Janz.

e-ISSN: 2474-1795 • http://scholarworks.iu.edu/iupjournals/index.php/jwp • doi: 10.2979/jourworlphil.1.1.04 
creation is not possible, or even that we should feel some sort of regret that the concept ever had that provenance.

How is this relevant for African philosophy, and for Chimakonam's argument? The discourse around African philosophy for decades has been one of defense and justification of an enterprise which, according to arbiters of philosophy outside of Africa, has no right to exist. As Chimakonam argues, there has been a great deal of metaphilosophy, most of it directed at understanding the scope and nature of African philosophy, and justifying its right to exist. But the moments of philosophical creativity have not yet been sufficiently analyzed, either as instructive historical moments or as present circumstances. Augustine certainly spent some of his time defending Christianity against non-Christians, but that was not the project of the Confessions, or for that matter of De Trinitate. He was grappling with an intellectual issue that presented itself in his place, which to be sure also had affective, emotional, and interpersonal elements.

Likewise, it seems to me that we are only coming to the point in African philosophy where the platial questions are driving research, both about the past and the present. One charge that someone might make against African philosophy from the outside might be that it is a regional philosophy, of interest only to those from that region. But that is the same misunderstanding that my student made when he rejected Augustine because he didn't share his religious interest. The point is not whether one can identify with the proponents, but whether one can access and understand the conversation that activates and authorizes a set of concepts in a place, and produces lines of flight (to use Deleuze's term) from that place. The point of engaging African philosophy by those outside of Africa is not just to understand Africa better, or to do comparative philosophy, it is to have access to a new ecology of concepts that, in the space of new encounters, might lead to yet further new concepts, along with new experiences, affects, and so forth.

Of course, the reasons for Africans to take African philosophy seriously, in this sense, is the same, but also more than that. It is to be part of asking the right questions, the new questions that are adequate to a place, the ones which do not just walk the same paths in the same way, but which walk the same paths in new ways, or which strike out on new paths. Those invested in a place have the responsibility to do more than just create a body of thought that reflects how "we" think about the world. That descriptive enterprise can simply become a tool of political or social control, rather than a moment of creativity. This is what I have sometimes wondered about the forms of African philosophy which purport to describe an "African view of X" - an African view of the person, an African view of ethics, etc. These projects look like they are adding something to the store of "world philosophy," but the effect, I think, is to reify a set of concepts as determinative for a people's intellectual milieu. It is, in other words, not the beginning of asking a new question, but instead it sets the boundaries and limits of what Africans can think and still be considered African. If, for instance, we talk about ethics, we have to at some point have an element of communitarian, "I am because we are" thought, because that's what makes African ethics uniquely African.

I don't think there is such a shibboleth of that sort for African thought. One rarely hears a concept ruled out of a conversation in Western thought on the basis that it is it is non-Western. The ruling out happens passively before that, through lack of awareness, lingering racism in the West, a host of structural factors related to access, and other things that mean that African and other non-Western ideas don't even cross the consciousness of philosophers. It isn't that philosophers don't engage concepts, it is often that they simply don't care about concepts that come from someplace other than the tried and true sources. But the fact is, there is also intellectual traffic across cultural borders all the time (even when it is not acknowledged as such, a point that the Afrocentrist project powerfully makes). Concepts travel, as Mieke Bal told us (Bal 2001), and that is a creative opportunity. ${ }^{4}$ And, just as concepts travel, they also change within cultural settings to respond to the imperatives of a time. Place becomes event, that is, place becomes not a static backdrop for intellectual life to happen, but it becomes the moments of virtuality, when a new concept opens up a new form of freedom in a place.

All of this leads to a question for Chimakonam: as he develops a fuller concept of philosophical space, is there a sense of how the interchange between places would actually occur in that space? As I have

Journal of World Philosophies 1 (Winter 2016): 41-50 
argued, my student's rejection of Augustine on the basis that he couldn't relate to his religious position and therefore couldn't understand his thought seems like a flawed stance, a stance that lacks imagination. But there might be a (slightly) more charitable interpretation of what my student said. It might not be that he couldn't relate, but that he didn't care. And care, in fact, might matter. Care is part of what matters in place-our concepts develop because they make a difference in that place, which is to say, people care about them. Out of the infinite number of concepts we could have, we do have a small subset, ones that matter. Can anything matter in philosophical space, and what is the nature of that mattering? Is it a shared mattering, that is, do different places come together to engage in thought because they both care about something, and if so, what does that mean? When we think about space geopolitically, it is usually about resources, territory, proximity, and so forth. In other words, states engage in debate because they have goals that would require some territory, and so they are playing for an advantage of some sort. That kind of account doesn't seem to work well for philosophy-it isn't clear that platial thinking is about that kind of advantage.

Another possibility is that philosophical space is simply agonistic space, that is, the space of the game, challenge, or test. It is not about establishing superiority but about honing one's own concepts by trying them against concepts of others. Chimakonam does seem to suggest this in the diagram on page 38. I read the diagram from bottom to top, that is, from a range of places at the bottom which rise up through parallel paths into philosophical space and comparative philosophy toward the top. They are presumably always rooted at the bottom, and always striving for the top. This is what he calls the Global Expansion of Thought (GET; for more on this see Chimakonam 2015b). ${ }^{5}$

The problematic that I see Chimakonam setting up here is around the question of how these places can remain true as places while at the same time striving for universal engagement. That engagement cannot fall into the patterns of domination and exclusion from the past, and so the usefulness of place is that it gives legitimacy to all forms of philosophy, and allows engagement to happen. But the question of care still hangs over this project. We can say that this interaction ought to happen, but what if no one cares to make it happen? Or what if the care is only on one side? It remains the case that African philosophers are far more open to engaging Western philosophy than the reverse. This, in my opinion, is very sad for the West and for the world, but if Western philosophers don't care, there is going to be little way of changing their minds. This is one reason why I set to the side the project of trying to convince those who don't see the value of philosophy outside of their own tradition that they ought to be more broad-minded.

The history of feminism is always one of my favorite examples here. For a very long time, feminism was seen as of interest only to women. The dominant male world of philosophy more or less ignored it. The dominant patriarchal nature of philosophy meant that the vast majority of philosophers just did not need to care. It was only once feminism turned from focusing on justifying the right of feminism to exist as a philosophy, and instead started to create concepts that could only be created from women's experience and women's perspectives that they were taken seriously. In other words, feminist philosophers worked from their place, and worried less about whether other philosophers cared. They developed new approaches in ethics, in epistemology, in just about every area of philosophy. And many of these concepts and approaches were very rich and were unquestionably new contributions to philosophy. At this point in history, in my opinion, one cannot credibly teach ethics or social philosophy or for that matter metaphysics and epistemology without taking feminist contributions into account. That came about not through conversation, but through a focus on developing and activating concepts in a unique place. Then the conversations became more urgent, as it became apparent that this was not just "comparative philosophy" between feminism and other areas, but a new wellspring of well thought-out concepts and approaches. 


\section{$3 \quad$ Philosophical Space}

Chimakonam's direct engagement with my work is around the concept of philosophical space (ibid: $31 \mathrm{ff}$ ). He argues that I have an incomplete development of the concept, preferring to work through platial philosophy, and he is certainly correct about that. To some extent a version of philosophical space has been developed, and I'm pushing back against it. In another sense, though, it has not been. But what do we mean by space in this context? If we begin with a version of place as I suggest, which is linked to virtualities, that is, the ability to produce a meaningful life that is tied to the particularities of place, how might we think about space? My argument has not been that we should ignore or dismiss space, but that we should not prioritize it. It does not come first. If we begin with place, we can move to space.

So, Chimakonam's point, that my version of space is too simplistic (ibid.: 35) is both correct but also I think not quite nuanced enough. What I did not develop sufficiently was not the concept of spatial philosophy as such, but the dynamics between platial and spatial philosophy. In Philosophy in an African Place, I worked with a binary which I think still has some usefulness, but which I also think was too crudely drawn. ${ }^{6}$ The binary depended on a distinction between an approach to intellectual geography which started from abstractions, and one which started from a phenomenology of place. I argued (and would still maintain) that a great deal of African philosophy until recent times has been preoccupied with carving out space on an intellectual map, laying claim to territory that had, in truth, been unilaterally claimed by nonAfricans in the past.

But the relationship is surely more complex than that. In this binary frame, space would always be derivative and secondary. Chimakonam is correct, then, that the distinction as it stands is simplistic. That does not mean, though, that I am ready to simply rehabilitate philosophical space in the form I sketched it earlier. Chimakonam asks for an agora, a ground or basis for philosophical exchange, and I agree that such a space requires theorization. He suggests that this is an agonistic space, and that too seems necessary to me, if not sufficient. But as I say, the question of the relationship of that space to place still requires reflection. If it is not simply an abstract precondition for African philosophy, as it has been in the past, is it then the space of contestation where philosophical place can work out its implications and establish lines of flight? Is this, then, a space that itself has no place, where concepts born in philosophical places come to engage each other? Is there any such space?

There are, I think, other options to the agonistic space which it seems that Chimakonam is pointing toward. We might, for instance, think of this space as territory, with its paths, borders, and practices of wayfinding based in past habitus and present circumstances. The metaphor is closer to that of animality, the ways in which territory is negotiated in ecological space, at multiple levels. Just as place is or can be multiple within one physical environment, so too can philosophical thought be multiple. I used the concept of "focal length" (Janz 2009: 231) when discussing topemes, and part of the reason for this was to identify the ways in which places were not just versions of an Aristotelean topos, in which place operates like a skin or layer which can be exchanged by objects as they move. Place is more than that, and a phenomenology of place requires that we be able to recognize not only that there are multiple lifeworlds within the same physical geography, but also that those lifeworlds might be embodied by the same people simultaneously. The concept of identity is sometimes used here, but I avoid that since there is a kind of essentialist echo there. It is not, in other words, that people have an identity, or have multiple ones, but rather that they navigate multiple places simultaneously, and one of the ways of navigating those places is to philosophize about them or in them.

Chimakonam wants a space of encounter and engagement, and I agree with him on this. But I am also aware of the limits of that space if it is simply thought as a prerequisite for philosophy. That is another outcome of my aforementioned discussion about dialogue (Janz 2015). The point there was that dialogue is something seen as a prerequisite to philosophy, which seems to place it beyond real philosophical interrogation. And yet, like Chimakonam, what I am calling dialogue and what he calls conversation is still

Journal of World Philosophies 1 (Winter 2016): 41-50 
necessary, because place itself requires it. Places (whether philosophical or otherwise) are not sealed units, sustained by their own internal practices. The borders are always porous, and places always exist as events, that is, as moments of coalesced meaning and action that has a provenance and points to a future. Those events happen in encounter, and they produce, among other things, concepts.

The depiction of concepts as being "about the most unfaithful, if not outright flirtatious entities in philosophy" (Chimakonam 2015a: 37) is as well-put as it is amusing. And, it is the reason why, in Philosophy in an African Place (Janz 2009), I talked about concepts that were "adequate" to their places, and in more recent work I have spoken about concepts as "activated" or "unactivated." To the extent that concepts are left unactivated, Chimakonam is undoubtedly correct. They are flirtatious and unfaithful, and we might add, they can be fetishized, idolized, and consumed. While the philosopher is the creator of the concept, that does not mean that every concept is worthwhile. But some concepts become activated, that is, they begin to build pathways around them. Some of those pathways we know as institutions. So, for instance, we have the concept of justice, around which we have a justice system. Of course, we know very well that this system obscures justice as often as it embodies it. We have the concept of race, around which we have a host of other concepts in a kind of ecology. We also have institutions such as disciplines, journals, laws, and so forth.

There are other concepts, similar in many ways, which are not activated. Take the concept of handedness, for instance. ${ }^{7}$ There are far more right-handed people in the world than left-handed, and it is clear that the world is constructed in many ways for right-handed people. And yet, we do not have the same kinds of institutions, conceptual ecologies, and so forth constructed around handedness that we do around race, gender, and so forth. There are few or no laws protecting the status of left-handed people. We do not focus on discriminatory language- "sinister," after all, comes from the Latin for left-handed whereas "dexterity" refers to the Latin for right-handedness. These are clearly morally loaded terms, and yet we do not include these in our discussions of sensitivity in language.

Handedness, in other words, is a concept, but not an activated one. It could be, but it is not. And if it were, we would be talking about discrimination, but we would also be talking about meaningful lifeworlds. Handedness would, in other words, become cultural at a different level than it is now. It would be a concept that activated other concepts, such as specific versions of freedom or the lack of freedom, of social marking and status, of the relationship between biology and culture, and so forth.

So, an activated concept is, in some sense, a way of thinking through how concepts actually operate in place. And this does not require us to think about an abstract pre-philosophical agonistic space, although it does require conversation, because activation cannot happen otherwise. My question for Chimakonam would be, is the space of conversation something that is essentially pre-philosophical, something that must be assumed in order for philosophy to begin, and if so, does its pre-philosophical status stand as an uninterpretable given, unavailable to phenomenological reflection? And if the answer to that is yes, does this not also mean that there is a stopping point for philosophy, a point past which philosophy cannot inquire?

\section{$4 \quad$ Wonder and African Philosophy}

Depending on the answer to the questions about philosophical space, we are led to a passing comment Chimakonam makes at the beginning of this essay. He refers to the "place and presence of 'wonder' in the philosophical activities of African philosophers today" (Chimakonam 2015a: 11), an idea that he also mentions at the end of his Internet Encyclopedia of Pbilosophy article on the history of African philosophy (Chimakonam 2016). ${ }^{8}$ I am interested in his conception of wonder, especially inasmuch as I see that he associates it particularly with the conversational school. Wonder is, of course, commonly seen as a fundamental feature of philosophy, ever since Socrates told us that "philosophy begins in wonder." But the 
provenance of wonder is not so clear. In a chapter in a recent book on neurophenomenology that I coauthored (Gallagher et. al 2015), we argued that there are in fact two strands of wonder today, which we called "ontological wonder" and "cognitive wonder". ${ }^{9}$ The first we have from the Platonic tradition, and the second from Spinoza, who reaches into Latin and the miracle (miraculum) tradition, from which we get admiratio or admiration. For Socrates and those in the thaumazein tradition, wonder delivers a deep and unseen order; it is a glimpse into the order of the gods' realm. For Spinoza, on the other hand, wonder is the experience of having a concept that is unconnected to any other concepts. It seems clear that there are differences between these two provenances for wonder. To quote from the chapter:

We'll call the first, the Greek thaumazein, 'ontological wonder' while the second, Spinoza's version derived from Latin, we'll call 'cognitive wonder.' The first emphasizes emotion (surprise) and perhaps revelation, while the second emphasizes concepts and their relation or lack thereof, and explicitly denies that wonder is emotion. The first is tied to action-wonder is not simply idle curiosity or puzzlement, but motivates reflective thought and is the basis for philosophy, while the second is produced by the mind's encounter with something that cannot be reduced to the realm of objects or causes, and may lead to emotion but need not motivate action. The first, ontological wonder, is tied to knowing our place in the cosmos and glimpsing something outside of that place (the sea, after all, was a source of mystery to the ancient Greek mind, since any kind of creature could emerge from it at any point). The second has nothing to do with our place, but rather has to do with the matrix of concepts. And, put most simply, philosophy may be based in thaumazein, or wonder, but is unlikely to be based in miraculum, or miracles (Gallagher et al. 2015: 118).

In other words, conceptually we have more than one line of provenance which yield quite different versions of wonder. Philosophers generally assume that they are heirs of Socrates and thaumazein, but there is clearly a separate line which Spinoza identifies. So an initial question here is: Is there a form of wonder that we can identify in an African tradition which is neither of these, or which partakes in a different conceptual ecology? This might seem like a tangential point to the central thrust of Chimakonam's paper, but I believe there is more to this than it seems. If philosophy begins in wonder, it is worth wondering what constitutes that state in different places. And, if we are taking place seriously, are we committed to some version of wonder which reveals place, which amounts to an event or uncovering of place? Does conversational philosophy, in its commitment to place (and this is a question as much for myself as it is for Chimakonam) also commit itself to an implicit transcendence of place? My own commitment has been to the emergence of new concepts, which suggests Spinoza's version of wonder as being significant.

One project that I would love to see African philosophers engage in would be a kind of philosophical genealogy, a return to the source. By that I do not mean another attempt to locate philosophy in some culturally ancient form, but rather, to think about the unique well-spring of concepts that continues to this day for African philosophy. If philosophy begins in wonder, what does that mean in a place like Africa (or to change the focal distance, a place like Nigeria, or South Africa, or Algeria)? Does it need to have the implicit transcendentalism of thaumazein or the unprecedented nature of cognitive wonder, or is there another wellspring of conceptual formation? That, in my mind, would be a never-ending quest, but that is, after all, what philosophy has always been.

This might be a possible answer to my earlier question, concerning the nature of philosophical space. My answer was to think in terms of the space of activated concepts, which would mean that there would be no philosophical space separate from place. But there is this other answer, which would be that the space would be the space of wonder, the space either of thaumazein (Socrates) or of concepts which are unrelated to other concepts (Spinoza). This, it seems to me, puts wonder almost outside of place, or perhaps as a limit to place (and place must, after all, always have limits). If philosophy is that form of inquiry and questioning that is not content to simply rely on established methods to find knowledge, but is truly willing to look at that which has not yet been examined, that which provokes wonder, we might have another version of philosophical space. It would not, perhaps, be the space in-between, the agonistic space, but 
rather the space beyond, that which place struggles to address but is bound to address. Some see this as the questioning of transcendence, some as the questioning of death or the nature of life or the nature of the universe; what these have in common is that they resist being satisfactorily answered using methods of science or other established inquiry.

In other words, in invoking wonder Chimakonam has introduced a concept which is suggestive and possibly could be newly productive in an African context. What is this space of wonder, and is it an alternative to the agonistic space of the encounter between concepts which arise from places? Without turning wonder into some mystical or mysterious force, is there a sense that wonder might be the event of place, that which gives place its urgency for those who are part of it? Or is wonder the edge of place, that which is not able to be included in one's conceptual ecology but which nevertheless makes a demand on that ecology?

The reason I make this detour into a discussion of wonder, based on the barest mention in Chimakonam's paper, is that it seems to me that it stands as an unexamined (and perhaps unexaminable) component of place and, perhaps also, philosophical space. In other words, instead of seeing conversation between places as a natural direction that thought will go once it is sufficiently self-aware, is it possible that conversation is driven by wonder in one of these senses described here? We would then have less of an agonistic space, but the price we might pay would be a return to a Platonic dialect, moving towards transcendence, at least if the version of wonder we assume is thaumazein. The fact that we can identify these Western conceptual ecologies for wonder is what makes me hope that reflection on an African arche might yield a version of wonder more indebted to African place.

\section{$5 \quad$ Conclusion}

Chimakonam's rich and provocative essay is a milestone of philosophy of place within an African context. He takes on the important question of what philosophical space might look like, and he is right to raise that question. I hope that my rejoinder here continues the conversation, and helps us all to think through the concepts that have become central for our sense of place.

Bruce B. Janz is Professor in the Department of Philosophy at the University of Central Florida, coDirector of the Center for Humanities and Digital Research, and graduate faculty in the Texts and Technology Ph.D. Program at UCF. He is the author of Philosopby in an African Place, co-author of $A$ Neurophenomenology of Awe and Wonder: Towards a Non-Reductionist Cognitive Science, and editor of the forthcoming Hermeneutics Place and Space, along with chapters and articles on theories of place and space, African philosophy, hermeneutics and phenomenology, Deleuze, digital humanities, and contemporary European philosophy. He has taught in Canada, the US, Kenya, and South Africa. 
1 Jonathan Chimakonam, "Conversational Philosophy as a New School of Thought in African Philosophy: A Conversation with Bruce Janz on the Concept of 'Philosophical Space'," Confluence: Online Journal of World Philosophies 3, (2015a): 9-40.

2 Bruce Janz, "Philosophy-in-Place and the Provenance of Dialogue," South African Journal of Philosophy 34, no. 4, (2015): 480-490.

3 Gilles Deleuze, and Felix Guattari, What Is Philosophy? New York: Columbia University Press, 1994.

$4 \quad$ Mieke Bal, Travelling Concepts in the Humanities: A Rough Guide, Toronto: University of Toronto Press, 2001.

5 Jonathan Chimakonam, "Transforming the African Philosophical Place Through Conversations: An Inquiry into the Global Expansion of Thought (GET)," South African Journal of Philosophy 34, no. 4, (2015b): 462-479.

6 Bruce Janz, Philosophy in an African Place, Lanham, MD: Lexington Books, 2009.

7 This example is from a lecture at Rhodes University that I did in September of 2015, which was the annual DCS Oosthuizen Memorial Lecture, devoted to academic freedom. It is developed more fully in Bruce Janz, "Free Space in the Academy", Journal of Academic Freedom 7 (Fall 2016). https://www.aaup.org/reportspublications/journal-academic-freedom/volume-7. Last accessed on 8 October 2016.

8 Jonathan Chimakonam, “African Philosophy, History of,” The Internet Encyclopedia of Philosophy, 2016 (ISSN 2161 0002, http://www.iep.utm.edu/afric-hi/; last accessed February 26, 2016).

9 Shaun Gallagher, Bruce Janz, Lauren Reinerman, Jörg Trempler, Patricia Bockelman, "The Phenomenology of Unprecedented Experience: Ontological and Cognitive Wonder" in A Neurophenomenology of Awe and Wonder: Toward a Non-Reductionist Cognitive Science, S. Gallagher et al., 115-129 (London: Palgrave MacMillan UK, 2015). 